Ольга Шинкаренко,

Національний університет оборони України імені Івана Черняховського, м. Київ ORCID ID 0000-0002-1958-171X

Дар'я Проноза,

Національний університет оборони України імені Івана Черняховського, м. Київ

ORCID ID 0000-0002-7286-1366

DOI: $10.33099 / 2617-1775 / 2021-02 / 305-314$

\title{
ВІДБІР ТА РЕДАГУВАННЯ АВТЕНТИЧНИХ ТЕКСТІВ ДЛЯ РОЗРОБЛЕННЯ ТЕСТОВИХ ЗАВДАНЬ 3 ЧИТАННЯ ДЛЯ ТЕСТІВ НА ВИЗНАЧЕННЯ ЗАГАЛЬНОГО РІВНЯ ВОЛОДІННЯ ІНОЗЕМНОЮ МОВОЮ ВІДПОВІДНО ДО СТАНДАРТУ НАТО СТАНАГ 6001
}

В статті обтрунтовується важливість використання автентичних текстів для розроблення тестів на визначення загального рівня володіння іноземною мовою у системі мовної підготовки ВВНЗ. Для ефективного очінювання навичок читання, тексти повинні бути ретельно відібрані, відредаговані, та відповідати опису рівнів складності, поданого у мовному стандарті НАТО СТАНАГ 6001.

Ключові слова: автентичний текст; відбір текстів; тест з читання; іншомовна компетентність; іншомовна підготовка; мовний тест; СТАНАГ 6001.

Постановка проблеми. Процес модернізації системи військової освіти передбачає впровадження вимог стандартів та процедур НАТО не лише у діяльність ЗС України, а й у військову освітню галузь, тому з метою досягнення взаємосумісності зі збройними силами країн-членів альянсу стає актуальним питання й мовної підготовки та мовного тестування, що також здійснюється у відповідності до стандартів НАТО. Оскільки одним із видів навчальних матеріалів, які сприяють ефективному оволодінню іноземною мовою та формуванню іншомовної компетентності, $є$ автентичні тексти, то й при розробці тестів теж доцільно використовувати лише автентичний матеріал. Автентичність текстів забезпечує природність їх лексичного наповнення, тому під час розроблення тестових завдань з читання гостро постає проблема відбору та редагування автентичних текстів.

Аналіз останніх досліджень i публікацій. Більшість досліджень зосереджено на питаннях використання автентичних матеріалів у процесі навчання іноземної мови, проте питання використання автентичних текстів для розроблення мовних тестів для оцінювання рівня загального володіння іноземною мовою у системі мовної підготовки ВВНЗ не отримало належного висвітлення у вітчизняних джерелах та потребує подальших досліджень. Дослідження питання використання автентичних матеріалів у навчанні іноземної мови та мовному тестуванні базується на аналізі праць вітчизняних та зарубіжних вчених та методистів [1-8], вимог нормативно-правових документів, що регулюють процес оцінювання рівня володіння іноземною мовою особового складу ЗС України [9-10], праць провідних фахівців з тестування [11-14], публікацій міжнародних екзаменаційних центрів 3 іноземних мов та 
рекомендацій експертів Бюро міжнародної мовної координації НАТО [15-18].

Мета статті с дослідження процесу відбору та редагування автентичних текстів для розроблення тестових завдань 3 читання для тестів на визначення рівня загального володіння іноземною мовою відповідно до стандарту НАТО СТАНАГ 6001.

Виклад основного матеріалу. У методиці викладання іноземних мов велика увага приділяється питанню використання автентичного (з грецької «справжній, оригінальний») матеріалу в процесі навчання. Т. Адамс вважає, що автентичні матеріали слід розрізняти від неавтентичних наступним чином. Автентичні матеріали - це матеріали, що було створені з метою спілкування у реальному світі. Неавтентичні матеріали створені спеціально для навчання, вони містять штучну мову, правильно оформлені речення і структуру, але $\epsilon$ дуже корисними для навчання граматичного матеріалу [8].

За визначенням С. Титової, автентичними текстами вважаються матеріали, взяті 3 оригінальних джерел, які характеризуються природністю лексичного наповнення та граматичних форм, ситуативною адекватністю використовуваних мовних засобів, що ілюструють випадки автентичного слововживання, і які, хоча і не призначені спеціально для навчальних цілей, але можуть бути використані при навчанні іноземної мови [4].

Поняття автентичності тексту не можна зводити лише до процесу добору лексики та правильного граматично оформленого висловлювання. Важливу роль у цьому процесі відіграє зміст навчального тексту.

Виділяють такі змістовні аспекти автентичності навчального тексту:

1. культурологічний (тексти, що розповідають про історію країни,

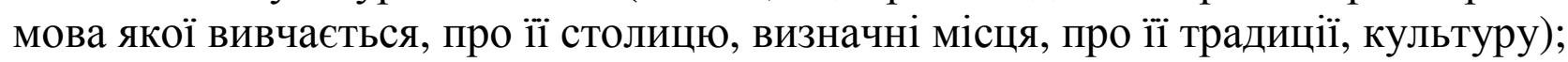

2. інформативний (природний текст, що містить нову інформацію, яка зацікавить читача);

3. с ситуативний (текст складається таким чином, щоб читач або слухач могли впізнати в ньому знайомий їм у повсякденному житті тип тексту. Це особисті листи, жарти, газетні статті тощо);

4. національна ментальність (коли автор тексту i читач $\epsilon$ представниками зовсім різних за своєю суттю культур, відмінних громадських позицій і цінностей);

5. автентичність навчальних завдань до текстів (текст здатний викликати емоційний, розумовий і мовний відгук).

Прикладами автентичних матеріалів як засобів навчання іноземних мов можуть бути мапи, меню, розклади, туристичні брошури, інформаційні листівки, рецепти, об'яви, пісні, уривки з теле- та радіоновин, листи, інтерв'ю, статті, країнознавчі тексти тощо.

Докладну класифікацію залежно від змісту, функцій у реальному середовищі і за тематикою пропонує К. Кричевська, яка поділяє всі автентичні матеріали на кілька груп, залежно від сфер спілкування:

1. навчально-професійна сфера спілкування: рекламні проспекти навчальних центрів, програми освіти у різних навчальних закладах, об'яви 3 
приводу роботи, різноманітні навчальні матеріали з іноземної мови, статті 3 газет, журналів;

2. соціально-культурна сфера спілкування: рекламні проспекти, довідники 3 ілюстраціями визначних місць, афіші спектаклів, концертів, фестивалів, запрошення, програми екскурсій, лотерейні квитки;

3. побутова сфера спілкування: предмети побуту та їх ілюстрації, схемиплани усіх видів транспорту, рахунки для сплати різних послуг, інструкції, пам'ятки до застосування побутових приладів;

4. торгово-комерційна сфера спілкування: рекламні проспекти товарів, запрошення-реклама, меню, рецепти національних страв;

5. сімейно-побутова сфера спілкування: матеріали листування (листи, листівки, телеграми, запрошення), візитні картки, бланки вітальних листівок;

6. спортивно-оздоровча сфера спілкування: реклама оздоровчих та спортивних центрів/комплексів, афіші масових спортивних змагань, рекламні проспекти лікувальних засобів та заходів [3].

На думку Е. Носонович та Р. Мільруд, критеріями відбору автентичних матеріалів називають параметри автентичних матеріалів, які є однозначно їх структурними ознаками: композиційна автентичність (змістовна та формальна цілісність тексту, міцні логіко-граматичні зв'язки між його складовими елементами); лексико-фразеологічна автентичність (застосування лексичних одиниць, типових для природного мовлення носіїв мов); граматична автентичність (використання притаманних мові граматичних структур); функціональна автентичність (природність відбору автентичних засобів для вирішення мовленнєвого завдання); культурологічна автентичність (насиченість країнознавчою інформацією); автентичність національної ментальності (урахування міжкультурних відмінностей); інформативна автентичність (зміст тексту повинен бути цікавим для студентів та відповідати їх віковим та індивідуальним особливостям); ситуативна автентичність (природність ситуації, що пропонується як навчальна ілюстрація); реактивна автентичність (здатність викликати у студентів автентичний емоціональний, розумовий та мовленнєвий зворотний зв'язок) [2].

Важливу роль у досягненні автентичності сприйняття тексту відіграє і його оформлення. Так, у сучасних підручниках об'ява подається у вигляді аркушу паперу, прикріпленого до стіни, стаття - у вигляді вирізки з газети, текст вітальної картки - у вигляді листа, написаного від руки тощо. Автентичне оформлення полегшує розуміння комунікативного завдання тексту, встановлення його зв'язків з реальністю.

Виходячи з усього вищезазначеного можна виділити вимоги, яким повинні відповідати автентичні тексти:

1. Використання автентичної лексики, фразеології.

2. Адекватність мовленнєвих засобів, що використовуються в запропонованій ситуації.

3. Природність пропонованих ситуацій.

4. Відображення особливостей культури та національного менталітету носіїв мови. 
5. Інформаційна та емоційна насиченість. [7]

3 вищенаведеним визначенням та ознаками автентичності матеріалів погоджуються й фахівці з мовного тестування. За визначенням експертів Бюро міжнародної мовної координації НАТО, автентичні тексти - це письмові чи усні зразки мовного матеріалу, які створені носіями мови для носіїв мови [17]. Автентичні тексти використовуються для розроблення тестових завдань 3 читання для стандартизованих мовних тестів, що використовуються у Міністерстві оборони України для оцінювання рівня загального володіння іноземною мовою військовослужбовців ЗС України. Мовні тести розробляються згідно з мовним стандартом НАТО СТАНАГ 6001, відповідно до результатів яких визначаються рівні мовленнєвої компетенції за чотирма видами мовленнєвої діяльності (аудіювання, говоріння, читання, письмо), які поділяються на шість стандартизованих мовленнєвих рівнів (СМР), від рівня СМР 0 до рівня СМР 5.

Метою тестів СТАНАГ $6001 \epsilon$ оцінювання спонтанних здібностей тестуємих у типових реальних комунікативних ситуаціях в іншомовному середовищі з рівнем точності та правильності, що очікується в такій ситуації. При розробленні тестових завдань рекомендується керуватись тематикою, зазначеною в СТАНАГ 6001 для відповідних рівнів: СМР 1 - «Рівень виживання», СМР 2 - «Функціональний рівень» тощо. Рекомендується створювати тестові завдання, які моделюють ситуації, з якими тестуємі можуть зіткнутись у реальному житті в іншомовному середовищі, та які перевіряють важливу i значущу інформацію, яка допоможе тестуємим ефективно вирішувати типові повсякденні та професійні завдання.

Розроблення тестових завдань починається з підбору тексту. Кожен текст підбирається відповідно до цільового рівня. Автентичні неадаптовані тексти слід використовувати для розроблення тестових завдань для рівнів СМР 2 і CMP 3. Тексти рівня СМР 1 можуть бути автентичними або частково автентичними, але вони мають бути справжніми. Справжній текст (англ. «genuine text») - це текст, який освічені носії мови сприймають як автентичний текст [17].

При відборі автентичних текстів в першу чергу слід керуватись специфікацією до тесту. Специфікація - це офіційний документ, в якому визначено, що саме має виміряти тест і в який спосіб він це зробить. В специфікація чітко визначено:

- для кого передбачено тест;

- 3 якою метою здійснюється вимір знань, умінь тощо;

- які саме знання, уміння та в якому обсязі мають бути перевірені;

- скільки частин буде містити тест для перевірки того, що планується перевірити;

- типи текстів, обсяг/тривалість текстів, тематика, діапазон словникового запасу, стиль тощо;

- типи завдань;

- скільки часу потрібно для виконання кожної частини і всього тесту загалом. 
- способи перевірки відповідей тощо [14].

При відборі автентичних текстів слід постійно пам'ятати про специфікацію до тесту та намагатись вибрати найбільш репрезентативний зразок тексту. Обсяг текстів повинен відповідати специфікації. Тематика текстів повинна міститись у переліку тем у специфікації. Для того, щоб забезпечити репрезентативну вибірку текстів, кожен рівень тестів 3 читання повинен містити 15-20 текстів різноманітної тематики [17].

Згідно $з$ мовним стандартом НАТО СТАНАГ 6001, тексти 3 читання на рівень СМР 1 можуть включати короткі нотатки, об'яви, прості описи людей, місць або речей, короткі та прості географічні відомості, інформацію про уряд і валютну систему країни, мова якої вивчається, прості інструкції (заяви, карти, меню, довідники, брошури, прості розклади тощо). Рівень СМР 2 включає повідомлення преси про звичайні, часто повторювані події суспільного життя, прості біографічні відомості, розповіді про поточні, минулі та майбутні події, звичайні ділові листи і прості технічні тексти, розраховані на широкий загал читачів [16].

Після відбору текстового матеріалу, його необхідно оцінити за наступним критеріями:

1. Чи є текст автентичним?

Автором тексту, як і цільовою аудиторією, для якої призначено текст, мають бути носії мови.

2. Чи є зміст тексту сучасним/застарілим?

Зміст тексту має бути сучасним та цікавим, але таким що не втратить актуальність через певний час, що дозволить використовувати тестове завдання тривалий час. Крім того, застаріла інформація, що міститься в текстах, може бути вже відома тестуємим.

3. Чи використовуються в тексті вузькоспеціалізовані технічні терміни, сленг, регіоналізми?

Тести на визначення рівня загального володіння іноземною мовою не призначені для перевірки глибини словникового запасу або спеціалізованої термінології в межах предметної області, отже слід уникати текстів із вмістом технічних термінів, сленгу, регіоналізмів тощо.

4. Чи обсяг (тривалість) та складність тексту відповідає рівню?

Ступінь складності текстів наведено в описі рівнів НАТО СТАНАГ 6001. Згідно рекомендацій Бюро міжнародної мовної координації НАТО, обсяг текстів з читання на рівень СМР 1 має бути до 60 слів (одне завдання до тексту), на СМР 2 - до 150 слів (одне-два завдання до тексту), на СМР 3 - до 300 слів (одне-два завдання до тексту) [17].

Слід уникати текстів, які містять:

- загальновідому інформацію;

- інформацію, для розуміння якої необхідно володіти поглибленими знаннями цільової культури поза межами знань тестуємих;

- інформацію, яка може засмутити чи викликати сильні негативні емоції у тестуємих, наприклад, аборт, згвалтування, катування, смерть тощо;

- образливі факти стосовно віку, статі, раси, релігії, етнічних рис, тощо; 
— лексику занадто високого або низького рівня складності;

- технічні чи стилістичні недоліки.

Ідеальний текст взагалі не має потребувати редагування. Однак деякі автентичні тексти, які є перспективними з точки зору розроблення тестових завдань, потребують певного коригування, щоб відповідати специфікації. Наприклад, занадто довгий текст необхідно скоротити, щоб він відповідав вказаній у специфікації кількості слів, яка допускається для тестових завдань відповідного рівня. При цьому важливо зберегти автентичність тексту. Наприклад, якщо текст, що складається 3 двох абзаців, можна скоротити, повністю видаливши другий абзац, це буде найоптимальнішим рішенням. Однак такий текст може здатися неповним, якщо не додати до нього одне чи два речення з видаленого абзацу [16].

Якщо текст містить занадто складну або просту для цільового рівня лексику, рідко вживані слова можна замінити на часто вживані (або навпаки), щоб текст більше відповідав цільовому рівню.

Текст, який $є$ перспективним для розробки тестових завдань, може містити імена політиків чи інших посадових осіб. В такому разі можна передбачити, що подібний текст скоро втратить актуальність. Доцільним рішенням при його редагуванні буде використання титулу або посади, а не імені згадуваної у тексті особи (наприклад, «Борис Джонсон» замінити на «прем'єр-міністр Великої Британії» тощо). Також допускається використання вигаданого імені замість справжнього.

Якщо текст містить конкретні дати, їх можна замінити умовними датами чи прислівниками часу (наприклад, «12 січня 2019 року відбулось...» замінити на «минулого січня/рік тому/нещодавно відбулось...» тощо) [18].

Текст може містити абревіатури, поширені в цільовій культурі, але мало відомі не носіям мови на мовних рівнях, які перевіряються. Такі абревіатури слід замінити повними назвами організацій чи понять.

Текст може містити друкарські помилки, які можуть відволікати увагу тестуємих. Такі помилки необхідно виправити.

Після здійснення редагування, розробникам тестових завдань слід проаналізувати відредагований матеріал, поставивши собі наступні питання:

- Чи в тексті дотримано правил правопису?

- Чи правильно розставлені розділові знаки?

- Чи зберігає відредагований матеріал достатню семантичну інформацію та зв'язність, щоб його можна було вважати «текстом»?

- Чи буде відредагований текст здаватись автентичним носіям мови?

Слід зауважити, що під час роботи з текстами може виникнути бажання вдосконалити чи виправити мову, зробити іiі більш вишуканою й літературною, чи краще відобразити цільову культуру. Такі виправлення можуть скласти хибне враження про цільову мову й насправді не бути автентичними. Розробникам тестових завдань слід уникати такого типу редагування [16].

Після редагування тексту необхідно попросити носія мови переглянути змінений текст, щоб пересвідчитись, що внесені зміни не вплинули на автентичність тексту. 
Висновки. Таким чином, нами визначено ознаки автентичності тексту, наведено класифікацію автентичних матеріалів залежно від їх тематики та функцій у реальному середовищі, визначено критерії відбору автентичних текстів, які $\epsilon$ вагомими як для навчання іноземної мови, так і для мовного тестування у системі мовної підготовки ВВНЗ, основними з яких є тематичність, комунікативність, функціональність, ситуативність, актуальність, відсутність упереджень, та відповідність специфікації до тесту. Наведено рекомендації щодо редагування автентичних текстів, які $є$ перспективними з точки зору розроблення тестових завдань.

Напрями подальших досліджень. Перспективи подальших досліджень відбору та редагування автентичних текстів для тестів на визначення загального рівня володіння іноземною мовою відповідно до стандарту НАТО СТАНАГ 6001 ми вбачаємо у детальній характеристиці відбору автентичних матеріалів для розроблення тестових завдань на рівень СМР 3 та СМР 4.

\section{ЛІТЕРАТУРА}

1. Методика навчання іноземних мов у середніх навчальних закладах: Підручник / Кол. авторів під керівн. С. Ю. Ніколасвої. - К.: Ленвіт, 1999. - 320 с.

2. Носонович Е. Критерии содержательной аутентичности текста / Е. Носонович, Р. Мильруд // Иностранные языки в школе. - 1999. - № 2. - 14 с.

3. Кричевская К. С. Прагматические материалы, знакомящие учеников с культурой и средой обитания жителей страны изучаемого языка. Иностранные языки в школе. 1996 . № 1. c. 13-17.

4. Титова С. В. Ресурси та служби Інтернету у викладанні іноземних мов / С.В. Титова. - M.: 2003. $-267 \mathrm{c}$.

5. Романюк Л.В., Русановська Т.В. Критерії відбору автентичних матеріалів у процесі навчання іноземної мови студентів немовних спеціальностей. Наукові записки Міжнародного гуманітарного університету, Одесса. Режим доступу до журн. : http://www.sci-notes.mgu.od.ua/archive/v27/40.pdf

6. Коротка Н. В. Роль автентичних матеріалів в вивченні ділової англійської мови. Наукові записки Національного університету «Острозька академія»: серія «Філологія». Острог: Вид-во НаУОА, 2018. Вип. 4(72), грудень. - 4 с.

7. Єременко І.І. Автентичні тексти як ефективний засіб формування іншомовної особистості студента. Вісник психології і педагогіки. Збірник наук. праць. - Випуск 11. K., 2013.

8. Adams T. What Makes Materials Authentic? (ERIC Document Reproduction Service No. ED 391389). - 1995. -8 p.

9. Концепція мовної підготовки особового складу Збройних Сил України та плану реалізації Концепції мовної підготовки особового складу ЗСУ: Наказ Міністра оборони України від 01 червня 2009 р. № 267. Київ : МО України, 2009. - 34 с.

10. Основні засади мовної підготовки особового складу у системі Міністерства оборони України. Наказ Міністерства оборони України від 08.08.2019 № https://nuou.org.ua/assets/documents/osn-zas-mp.pdf

11. Квасова О.Г. Основи тестування іншомовних навичок і вмінь: Навчальний посібник. - К.: Ленвіт, 2009. - 119 с.

12. Булах І. Є. Створюємо якісний тест: навч. посіб. / І. Є. Булах, М. Р. Мруга. .- К.: Майстер-клас, 2006. - 160 с.

13. Hughes, A. Testing for Language Teachers, second edition. Cambridge: Cambridge University Press, 2011. -251 p. 
14. Alderson, Ch.J., Clapham C., Wall D. Language Test Construction and Evaluation. Cambridge: Cambridge University Press, 1995. - 324 p.

15. ETS Guidelines for Fair Tests and Communications. Educational Testing Service, 2016. - 68 p.

16. BILC Language Testing Seminar, 9-20 February, 2015.

17. BILC Best Practices in STANAG 6001 Testing, March 2019. - 13 p.

18. Clifford, R. Making Authentic Language Proficiency Tests Based on STANAG 6001 Standards. BILC Seminar in Budapest, October 2016. - 41 p.

\section{REFERENCES}

1. Methods of teaching foreign languages in secondary schools: Textbook / Col. authors under the guidance of S. Nikolaeva. - K .: Lenvit, 1999. - 320 p.

2. Nosonovich E. Criteria for substantive authenticity of the text / E. Nosonovich, R. Milrud // Foreign languages in school. - 1999. - № 2. - 14 p.

3. Krichevskaya K. Pragmatic materials, acquainting students with the culture and habitat of the residents of the country of the studied language. Foreign languages at school. 1996. № 1. p. 13-17.

4. Titova S. Resources and services of the Internet in teaching foreign languages / SV Titova. Titova. - M .: 2003. - 267 p.

5. Romanyuk L., Rusanovskaya T. Criteria for selection of authentic materials in the process of teaching a foreign language to students of non-language specialties. Scientific notes of the International Humanities University, Odessa. Journal access mode.: http://www.scinotes.mgu.od.ua/archive/v27/40.pdf

6. Korotka N. The role of authentic materials in the study of business English. Scientific notes of the National University "Ostroh Academy": series "Philology". - Ostrog: NaUOA Publishing House, 2018. V. 4 (72), December. - 4 p.

7. Yeremenko I. Authentic texts as an effective means of forming a student's foreign language personality. Bulletin of psychology and pedagogy. Collection of sciences. wash. - Issue 11. - K., 2013.

8. Adams T. What Makes Materials Authentic? (ERIC Document Reproduction Service No. ED 391389). - 1995. - 8 p.

9. The concept of language training of personnel of the Armed Forces of Ukraine and the implementation plan of the Concept of language training of personnel of the Armed Forces: Order of the Minister of Defense of Ukraine of June 1, 20092009 267. Kyiv: Ministry of Defense of Ukraine, 2009. - 34 p.

10. Basic principles of language training of personnel in the system of the Ministry of Defense of Ukraine. Order of the Ministry of Defense of Ukraine dated 08.08.2019 № https://nuou.org.ua/assets/documents/osn-zas-mp.pdf

11. Kvasova O. Basics of testing foreign language skills and abilities: Textbook. - K.: Lenvit, 2009. - $119 \mathrm{p}$.

12. Bulakh I. We create a quality test: textbook. / I. Bulakh, M. Mruga. - K.: Master-class, 2006. - $160 \mathrm{p}$.

13. Hughes, A. Testing for Language Teachers, second edition. Cambridge: Cambridge University Press, 2011. - 251 p.

14. Alderson, Ch.J., Clapham C., Wall D. Language Test Construction and Evaluation. Cambridge: Cambridge University Press, 1995. - 324 p.

15. ETS Guidelines for Fair Tests and Communications. Educational Testing Service, 2016. - 68 p.

16. BILC Language Testing Seminar, 9-20 February, 2015.

17. BILC Best Practices in STANAG 6001 Testing, March 2019. - 13 p.

18. Clifford, R. Making Authentic Language Proficiency Tests Based on STANAG 6001 Standards. BILC Seminar in Budapest, October 2016. - 41 p. 


\title{
PEЗЮME
}

Ольга Шинкаренко,

Национальный университет обороны Украины имени Ивана Черняховского

Дарья Проноза,

Национальный университет обороны Украины имени Ивана Черняховского

\section{Отбор и редактирование аутентичных текстов для разработки тестовых заданий по чтению для тестов на определение общего уровня владения иностранным языком в соответствии со стандартом НАТО СТАНАГ 6001}

В статье обосновывается важность использования аутентичных текстов для разработки тестов на определение общего уровня владения иностранным языком в системе языковой подготовки ВВУЗ. Для эффективного оценивания навыков чтения, тексты должны быть тщательно отобраны, отредактированы, и соответствовать описанию уровней сложности, поданного в языковом стандарте НАТО СТАНАГ 6001.

Ключевые слова: аутентичный текст; отбор текстов; тест по чтению; языковая компетентность; языковая подготовка; языковое тестирование; СТАНАГ 6001.

\section{SUMMARY}

\author{
Olha Shynkarenko, \\ Senior Research Fellow \\ National Defence University of Ukraine \\ named after Ivan Cherniakhovskyi \\ Daria Pronoza, \\ Research Fellow \\ National Defence University of Ukraine \\ named after Ivan Cherniakhovskyi
}

\section{Selection and editing of authentic texts for development of reading test tasks for language proficiency tests in accordance with NATO STANAG 6001}

The article examines the importance of using authentic texts for the language proficiency tests development in the language training system of military higher education institutions. For effective evaluation of reading comprehension, texts should be carefully selected, edited, and be consistent with the language proficiency levels described in NATO Standardization Agreement (STANAG) 6001 .

The main goal of STANAG 6001 language proficiency tests is to assess a test-taker's unrehearsed general language proficiency level for the purpose of interoperability within NATO using the criteria described in STANAG 6001 proficiency scales and to measure a test taker's spontaneous ability to fulfill the real-world communication tasks in the frequently-occurring realworld communicative settings with the level of accuracy expected in those situations.

Authentic texts are written or spoken by native speakers for native speakers. The main criteria for selection of authentic texts that are important for language testing in the language training system are communicativeness, functionality, relevance, absence of prejudices, and compliance with the test specifications.

The ideal text would require no editing at all. However, some authentic texts will seem promising for testing purposes but require some adjustment to fit test specifications. Following editing, test writers should review their work by asking the following questions: Is all spelling and punctuation correct? Does the edited material retain semantic information and cohesion so that it can reasonably be considered a "text"? Would native readers/listeners find the edited text awkward 
or inauthentic?

Reading test tasks developed from authentic texts will prepare test takers for communication tasks they may deal with in the foreign language communicative setting and will allow determining which STANAG 6001 level best describes the test taker's level of sustained ability.

Key words: authentic text; text selection; reading test; foreign language proficiency; language training; language testing; STANAG 6001. 